\title{
Administration Oral Misoprostol after Radical Hysterectomy Due to Cervical Cancer in the Early Stage Decrease Urinary Retention Incident
}

\author{
Pemberian Misoprostol Per Oral Pascahisterektomi Radikal pada Karsinoma Serviks \\ Stadium Awal untuk Menurunkan Insiden Retensio Urin
}

\author{
Rajuddin , Lutfi, Hasanuddin \\ Department of Obstetric Gynecology, \\ Faculty of Medicine Universitas Syiah Kuala \\ Dr. Zainoel Abidin Hospital, Banda Aceh
}

\begin{abstract}
Objective : To determine the effect of oral Misoprostol after Radical Hysterectomy in the early stage Cervical Cancer to reduce the incidence of urinary retention.

Methods : The study was conducted with a prospective cohort method, randomized control trial and double-blind to the patients with early-stage cervical cancer who performed Radical Hysterectomy in Dr. Zainoel Abidin hospital, Banda Aceh. There are 34 subjects who agreed to participate in the study. Subjects were divided into 2 groups. The first group who received Misoprostol orally as the intervention group and the other group that received placebo as the control group.

Results : The incidence of urinary retention after Radical Hysterectomy in Dr. Zainoel Abidin hospital, Banda Aceh, decreased significantly in the intervention group compared to the control group ( $\mathrm{P}$ 0,049). In the intervention group Misoprostol reduce residual urine. Ability to void spontaneously and urine volume were increase. The duration of catheterization and length of hospital stay for the patients were shorter.

Conclusions : Administration of Misoprostol orally reduce the incidence of urinary retention after Radical Hysterectomy. Oral Misoprostol can be recommended as an additional procedure to reduce urinary retention.
\end{abstract}

Keywords : cervical cancer, misoprostol, radical hysterectomy, urinary retention.

\begin{abstract}
Abstrak
Tujuan : Untuk mengetahui pengaruh pemberian Misoprostol per oral pascaoperasi Histerektomi Radikal pada pasien karsinoma Serviks stadium awal terhadap insidensi retensio urin.
\end{abstract}

Metode : Penelitian dilakukan dengan metode kohort prospektif, randomized control trial dan double blind, pada pasien karsinoma serviks stadium awal yang dilakukan Histerektomi Radikal di RS dr. Zainoel Abidin, Banda Aceh. Terdapat 34 pasien yang telah menyetujui mengikuti penelitian, yang dibagi dalam 2 kelompok yaitu kelompok yang mendapat Misoprostol tablet peroral sebagai kelompok perlakuan dan kelompok yang mendapat plasebo sebagai kelompok kontrol. Residu urin pada kedua kelompok diukur dan faktor-faktor lain yang terkait dilakukan pendataan untuk dilakukan analisis.

Hasil : Kejadian retensio urin pascahisterektomi Radikal di RS dr. Zainoel Abidin, Banda Aceh, menurun secara bermakna pada kelompok perlakuan dibandingkan kelompok kontrol (P0,049). Pada kelompok perlakuan Misoprostol menurunkan residu urin. Peningkatan kemampuan berkemih spontan dan volume urin .lama pemakaian kateter transuretra dan lama perawatan menjadi lebih singkat.

Kesimpulan : Pemberian Misoprostol per oral mengurangi insiden retensio urin pascahisterektomi Radikal.

Saran : Misoprostol per oral dapat direkomendasikan sebagai prosedur tambahan untuk mengurangi retensio urin.

Kata kunci : karsinoma serviks, histerektomi radikal, misoprostol, retensio urin. 


\section{INTRODUCTION}

Cervical cancer ranks second in Indonesia due to the number of cancer patients in women but as a cause of death was the first rank. Based on WHO data (World Health Organization) in 2008 it is estimated that every day there are 38 new cases of Cervical Carcinoma and 21 women who died of Cervical Cancer in Indonesia. ${ }^{1}$ Based on 2013 Riset Kesehatan Dasar (Riskesdas) conducted by the Ministry of Health Litbangkes, prevalence of sufferers cervical cancer in Aceh Province is equivalent to prevalence of Indonesian national cervical cancer, which is 1.4 / 1,000 population or two people per 1,000 population. $^{2}$ Based on secondary data from Zainoel Abidin General Hospital Banda Aceh in 2013, the majority of cases of Cervical Cancer (61\%) wherein the early stages (stadium 1A, stadium 1B and stadium IIA). ${ }^{3}$

Urinary retention is the most frequent complication of surgery Radical Hysterectomy of the Early-stage Cervical Cancer and causes voiding dysfunction with an incidence of $8 \%$ $80 \%$. Twenty of percent of patients who have had a Radical Hysterectomy developed Vesika Urinary dysfunction up to 3 months postoperatively. ${ }^{4-6}$

Misoprostol is a drug that is often used for the treatment of urinary retention. The effects of these drugs can increase Detrusor muscle contractions. Misoprostol is a PGE1 derivative. Pharmaco kinetic Oral administration of Misoprostol is more rapidly absorbed than intravaginal administration. ${ }^{7-9}$ The authors want to prevent the occurrence of Urinary Retention by administering Misoprostol orally as a prophylaxis to reduce bladder dysfunction morbidity. Therefore the authors are interested in assessing the effectiveness of Misoprostol per oral administration to reduce the incidence of urinary retention after Radical Hysterectomy.

\section{METHODS}

This research design is a Randomized Control Trial, Double blind study. The group was given oral Misoprostol tablets with a catheter after Radical Hysterectomy was called the intervention group and the group was given a placebo with a catheter as the control group. The study was conducted after the ethical clearance approved by ethical committee, at the Division of Gynecology Oncology, Zainoel Abidin general Hospital Banda
Aceh and started from January 2017 to October 2018. The target population in this study were all patients who have had Radical Hysterectomy in the early stage Cervical Cancer (stage 1A, 1B, $2 A)$.

Inclusion criteria were: patients after radical hysterectomy in the early stage cervical cancer and agreed to take part in the study by signing an informed consent. Exclusion criteria were patients with a history of urinary retention before surgery, urinalysis and LEA tests showing urinary tract infections, hydronephrosis, chronic urinary retention and urinary incontinence, Urethral stricture and history of Vesika Urinary injury. The number of subjects in this study were 34 patients consisting of 17 intervention groups and 17 control groups. The randomization method used SNOSE (sequentially, numbered, opaque, sealed, sealed envelope) or using sequential, numbered envelopes, envelopes that are not transparent and closed.

Patients were given oral misoprostol tablets $200 \mu \mathrm{g}$ per 12 hours, within 24 hours after radical hysterectomy. All patients have a transurethral catheter placed after surgery hysterectomy for emptying the bladder for $1 \times 24$ hours. After the catheter is removed the patient is observed, as follows: Within 6 hours of observation, the patient is given a drink water $100 \mathrm{cc}$ per hour. If the patient wants and able to void spontaneously, perform measurement for residual urine using a catheter. If residual urine is less than $100 \mathrm{ml}$, then the patient is considered capable of spontaneous voiding. If residual urine is $100-500 \mathrm{ml}$ or more, the patient has urinary retention and continue to urinary retention management. If within 6 hours observation the patient is unable to void spontaneously, the patient's urine will be removed by transurethral catheter for 24 hours. Observation of the research will be carried out until the patient can spontaneously urinate again with urine residue less than $100 \mathrm{ml}$ and suitable for discharged from the hospital. Data collection of factors related to urinary retention after radical hysterectomy were: bladder capacity, spontaneous voiding time, urine volume, length of stay, intraoperative blood loss, time of surgery for radical hysterectomy and side effects of Misoprostol. Data will be analyzed using the SPSS 22 software with significance $P$-value $<0.05$. 


\section{RESULT}

During the study period, we included 34 research subject who met our inclusion and exclusion criteria. General characteristics of study subject are shown in table 1.

Table 1. General Characteristic of Research Subject

\begin{tabular}{|c|c|c|}
\hline Variable & Frequency (n) & (\%) \\
\hline Intervention group (Misoprostol) & 17 & 50 \\
\hline Control group (Placebo) & 17 & 50 \\
\hline \multicolumn{3}{|l|}{ Urinary retention } \\
\hline Control & 13 & 38.2 \\
\hline Intervention & 3 & 8.8 \\
\hline \multicolumn{3}{|l|}{ Without urinary retention } \\
\hline Control & 4 & 11.7 \\
\hline Intervention & 14 & 41.3 \\
\hline \multicolumn{3}{|l|}{ Age } \\
\hline $40-45$ & 4 & 11.7 \\
\hline $46-50$ & 4 & 11.7 \\
\hline $51-55$ & 12 & 35.3 \\
\hline $56-60$ & 11 & 32.3 \\
\hline $61-65$ & 2 & 5.8 \\
\hline $65-70$ & 1 & 3.2 \\
\hline underweight & 0 & 0 \\
\hline Normal & 27 & 79.4 \\
\hline Overweight & 5 & 14.7 \\
\hline Obesity & 2 & 5.9 \\
\hline \multicolumn{3}{|l|}{ Parity } \\
\hline Parity 1 & 0 & 0 \\
\hline Parity 2-4 & 15 & 44.1 \\
\hline Parity $>4$ & 19 & 55.9 \\
\hline \multicolumn{3}{|l|}{ Cervical Cancer Staging } \\
\hline Stage $1 \mathrm{~A}$ & 1 & 2.9 \\
\hline Stage 1B & 15 & 44.1 \\
\hline Stage $2 \mathrm{~A}$ & 18 & 53 \\
\hline \multicolumn{3}{|l|}{ Able to void spontaneously } \\
\hline Control & 11 & 32.3 \\
\hline Intervention & 17 & 50.1 \\
\hline \multicolumn{3}{|l|}{ Unable to void spontaneously } \\
\hline Control & 6 & 17.6 \\
\hline Intervention & 0 & 0 \\
\hline \multicolumn{3}{|l|}{ Intraoperative bleeding $\geq 500 \mathrm{cc}$} \\
\hline Urinary retention & 12 & 35.3 \\
\hline Without urinary retention & 7 & 20.5 \\
\hline \multicolumn{3}{|l|}{ Intraoperative bleeding $<500 \mathrm{cc}$} \\
\hline Urinary retention & 4 & 11.7 \\
\hline Without urinary retention & 11 & 32.5 \\
\hline
\end{tabular}

\section{Correlation between Administration Misoprostol Tablets and placebo to Residual Volume after Catheter Removal}

In 34 patient, 6 research subject were found in the control group who were unable to void spontaneously after catheter removal, only 11 research subject residual urine could be measured. All intervention groups were able to void after catheter removal, resulting in 17 research subject of residual urine that could be measured. The statistical calculation showed that the independent sample test results with P-value 0.049, which means there are significant differences. Based on the data that the administration of misoprostol after radical hysterectomy can reduce the residual urine.

Table 2. Correlation between the Administration of Misoprostol Tablets with Mean Urine Residual Volume

\begin{tabular}{lccc}
\hline Group & Total Case & $\begin{array}{c}\text { Mean urine } \\
\text { residual volume }\end{array}$ & SD \\
\hline Intervention & 17 & $52.6 \mathrm{ml}$ & 47.9 \\
$\begin{array}{l}\text { Control } \\
\mathrm{P}=0.049\end{array}$ & 11 & $159.5 \mathrm{ml}$ & 155.6 \\
\hline
\end{tabular}

\section{Correlation between Administration of Misoprostol Tablets and Volume of Residual Urine $\mathbf{1 0 0 ~} \mathrm{ml}$ or more (Urinary Retention)}

In 34 patient who has had radical hysterectomy, there were 16 research subject with residual urine $100 \mathrm{ml}$ or more after transurethral catheter removal. Thirteen (38.2\%) cases were from the control group and 3 cases (8.8\%) from the intervention group. In the statistical calculation using the Chi-square test, the difference between the occurrence of urine residual volume of $\geq$ $100 \mathrm{ml}$ between these groups is significant with P-value 0.002. These findings show that administration of misoprostol tablets after radical hysterectomy can reduce residual urine volume to less than $100 \mathrm{ml}$.

Table 3. Correlation between the Administration of Misoprostol Tablets and Volume of Residul Urine $\geq 100 \mathrm{ml}$ (urinary retention)

\begin{tabular}{lcc}
\hline Group & $\begin{array}{c}\text { Urine residual volume } \\
\geq \mathbf{1 0 0} \mathbf{~ m l}\end{array}$ & $\begin{array}{c}\text { Urine residual volume } \\
<\mathbf{1 0 0} \mathbf{~ m l}\end{array}$ \\
\hline Control & 13 Cases (38.2\%) & 4 Cases $(11.7 \%)$ \\
Intervention & 3 Cases (8.8\%) & 14 Cases $(41.3 \%)$ \\
Total Cases & 16 & 18 \\
$\mathrm{P}=0.002$ & & \\
\hline
\end{tabular}

\section{Correlation between Administration of Misoprostol Tablets with Spontaneous Voiding ability}

There were 6 research subject unable to void spontaneously (17.6\%) all of which occurred in the control group. All patients (17 research subject (50.1\%)) in the intervention group were able to void spontaneously, whereas in the control group there were 11 research subject were able to void spontaneously (32.3\%). Statistical calculations 
using the Chi-square test, the difference between the administration of misoprostol tablets and the ability to void spontaneously after catheter removal between these groups were significant with P-value 0.018.

\section{Correlation between Administration Misoprostol Tablets and Bladder Capacity}

In the control group there were 11 research subject were able to void spontaneously with mean bladder capacity $327,2 \mathrm{ml}$. All patient in the intervention group were able to void spontaneously with mean bladder capacity 360,5 $\mathrm{ml}$. In the statistical calculation of this study using the independent sample test, the P-value 0.479 . It means that there is no significant difference in bladder capacity between the intervention group and the control group. It can be concluded that administration Misoprostol after radical hysterectomy has no effect on bladder capacity.

\section{Correlation between Administration Misoprostol Tablets and the First Time of Voiding Postradical Hysterectomy}

Based on the data of the first voiding response after radical hysterectomy, it shows the first time of voiding after radical hysterectomy in the intervention group more faster than the control group (117.6 vs 237.2 minutes). In the statistical calculation using the independent sample test obtained P 0.001, which means there are significant differences.

\section{Correlation between the Administration of Misoprostol Tablets with Length of Hospital Stay}

Based on statistical calculations using the independent sample test, the difference in length of hospital stay between the intervention and control groups was significant with a P-value of 0.001 . The mean length of hospital stay in the intervention group was 3.3 days, while the average length of the control group was 4.8 days. The data showed that the length of hospital stay in the intervention group was more shorten than the control group.

\section{Correlation between Retention of Urine and} Amount of Intraoperative Bleeding

In this study, an amount of intraoperative bleeding depends on the stage of cervical cancer and the extent of the operating area. Urinary retention with the amount of intraoperative bleeding > $500 \mathrm{cc}$ was found in 12 (35\%) research subject and 7 (20.5\%) research subject without urinary retention. In the case of radical hysterectomy with intraoperative bleeding $\leq 500,4$ (11.7\%) research subjects have had urinary retention and 11 without urinary retention (32.3\%). The results of statistical analysis using the Chi-square test obtained P-value 0.07 this data showed no significant differences.

\section{Side Effect}

The administration of misoprostol orally 200 micrograms every 12 hours did not have serious side effects, and no patients dropped out from this study. Three of the 17 patients were administered misoprostol, complained of cramping in the abdominal wall with mild intensity and transient abdominal pain. These side effects do not require treatment and always self-limiting. Other side effects such as diarrhoea, chest pain, hypotension, arrhythmia and shivering were not found in both groups.

\section{DISCUSSION}

Residual urine is affected by Detrusor muscle contractions. The physiology of voiding and bladder emptying process play a role in decreasing residual urine. Misoprostol, a PGE1 analogue causes open calcium channels so that extracellular calcium will easily enter the intracellular and bind to calmodulin which will activate the formation of MLC Kinase which facilitates the formation of P-Myosin. The myosin crossbridge to bind the actin filament to allow contraction of the detrusor muscle. Oral administration of misoprostol after radical hysterectomy can reduce residual urine volume. This condition is caused by the ability of prostaglandin to improve tone recovery and detrusor bladder muscle activity so that the 
bladder's ability to empty all of the urine more better. Normal voiding requires an adequate Detrusor tone and low resistance to the bladder neck and urethra. ${ }^{10,11}$ This study shows that misoprostol can increase the contraction of detrusor muscle.

Administration of misoprostol tablets after radical hysterectomy can reduce residual urine volume to less than $100 \mathrm{ml}$ and increase spontaneous voiding ability. ${ }^{12,13 T}$ his also corresponds with research that prostaglandin can accelerate recovery and activate detrusor bladder muscle tone. Existing literature found significant differences after vaginal hysterectomy procedure which given a prostaglandin $1.5 \mathrm{mg}$ analogue intravaginally. Regarding to the study the mean residual urine significantly decrease. ${ }^{14,15}$

Pathophysiology mechanism of lower urinary tract function changes after radical hysterectomy. The urinary bladder wall undergoes decline in the elastic muscular properties caused by surgical injury and partial damage from the autonomic bladder innervation. ${ }^{16-18}$ Literature revealed that the rate of postoperative voiding dysfunction depends on the resection of vaginal, paravaginal and parametrial tissue. ${ }^{19,20}$ In Literature, $47 \%$ of women in the early stage cervical cancer post radical hysterectomy undergo urinary retention with residual urine $\geq 100 \mathrm{ml}$. In general, the initial transient changes after radical hysterectomy consist of reduced bladder capacity, detrusor hypoactivity, and reduced bladder sensation.

Literature has shown that decline in bladder compliance occurs after radical hysterectomy. ${ }^{21,22}$ The data shows the first time of voiding after radical hysterectomy in the intervention group more faster than the control group (117.6 minutes vs 237.2 minutes, $P<0.001)$. The administration of misoprostol can shorten the first time of voiding after radical hysterectomy, improve compliance and increase the proprioceptive sensation and bladder sensation.

In this study showed a significant increase in urine volume in the intervention group after radical hysterectomy $(312.6 \mathrm{ml}$ vs. $201.3 \mathrm{ml}$ ). Based on statistical calculations, there are significant differences so that oral administration of misoprostol after radical hysterectomy can increase urine volume.

Administration of misoprostol tablets after radical hysterectomy can reduce the length of stay and reduce residual urine. This data corresponds that length of stay postoperative ranging from 1 to 6 days. Bergman's research stated that giving Misoprostol will shorten the length of stay. ${ }^{23}$

An amount of intraoperative bleeding after radical hysterectomy showed that there was no significant difference in cases of bleeding more than 500 cc or less than $500 \mathrm{cc}$ due to occurrence of urinary retention, so it can be concluded that the incidence of urinary retention was not related to an amount of intraoperative radical hysterectomy. Urinary retention was associated with an amount of intraoperative bleeding correspond to the research which stated that urinary retention was not caused by intraoperative bleeding, but was probably due to an expansion of the operating area which could cause innervation of Pelvicus nerve in the lower urinary tract. 24,25

\section{CONCLUSION}

Oral administration of misoprostol tablets can reduce the incidence of urinary retention after radical hysterectomy. Oral administration of misoprostol tablets can reduce residual urine volume, increase spontaneous voiding ability, increase urine volume, shortening the first time of voiding after radical hysterectomy and reduce length of hospital stay. There was no significant correlation with oral misoprostol tablets with decreased bladder capacity. An amount of intraoperative bleeding has no significant correlation with the incidence of urinary retention.

\section{RECOMMENDATION}

The author recommend that a larger sample group can yield more accurate study result. Expanding research variables and conducting pre-operative examinations to measure detrusor muscle strength and urethral resistance. 


\section{REFERENCES}

1. Ocviyanti D, Handoko Y. Peran Dokter Umum dalam Pencegahan Kanker Serviks di Indonesia. J Indones Med Assoc 2013; 63: 1-3.

2. Riskesdas 2013. Prevalensi kanker di Aceh 2013. Jakarta (indonesia) : RAIC.c2014

3. Lusiana a. Faktor Risiko Kanker Serviks di RSUD dr. Zainoel Abidin Banda Aceh pada tahun 2013. J Kes 2013; 1: 5-8.

4. Lykke R, Blaakaer J, Ottesen B. et al (2016). Incidence of pelvic organ prolapse repair subsequent to hysterectomy: a comparison between radical hysterectomy and total abdominal hysterectomy. Int Urogynecol J. 2013;171:333-8.

5. Marin F, Plesca M, Bordea C, et al. Postoperative surgical complication of lymphadeno hystereocolpectomy. J Med Life. 2014;7(1):60-6.

6. Fuglsang $K$, Petersen LK, Blaakaer J. Addressing challenges in future surveillance after surgery for earlystage cervical cancer. Int J Gynecol Cancer. 2015;25:30914.

7. Morris J, Winikoff B, Dabash R. FIGO's updated recommendations for misoprostol used alone in gynecology and obstetrics. Int J Gynecol Obstet. 2017; 1(1):1-4.

8. Marret $\mathrm{H}$, Simon $\mathrm{E}$, Dreyfus $\mathrm{M}$, et al. Overview and expert assessment of off-label use of misoprostol in obstetrics and gynaecology: review and report by the Collège national des gynécologues obstétriciens français. Eur J Obstet Gynecol Reprod Biol. 2015;187: 80-4.

9. Chaurasia, Amrita, Tyagi. Persistent postpartum urinary retention following vaginal delivery: a rare complication in obstetrics practice. Int J Reprod, Contracept, Obstet Gynecol.2013; 2: 475.

10. AzamiDA. PostVoid Residual Reduction by Administering Misoprostol during post Caesarean Section. Maj Obstet Ginekol. 2013;21:104-8.

11. Roxane C. Handal O, Sujata M, et al. Association of oral misoprostol with cesarean delivery. Am J Obstet Gynecol. 2017;216(1):400.

12. Yoshida M, Yamaguchi O. Detrusor Underactivity: The Current Concept of the Pathophysiology. Lower Urinary Tract Symptoms. 2014; 6:131-7.

13. Laterza RM, Sievert KD, Ridder $D$, et al. Bladder function after radical hysterectomy for cervical cancer.Neurourol Urogynecol. 2015;34(4):309-15.
14. Geller EJ. Prevention and management of postoperative urinary retention after urogynecologic surgery. Int J Women's Health. 2014;6:829-38.

15. Hegele $A$, Knippschild $S$, Olbert $P$, Hofmann $R$. Changes in prostaglandin E2 in patients with idiopathic overactive bladder syndrome after botulinum toxin type A treatment: is there a clinical benefit?. BMC Urol. 2014;14:85.

16. Maneschi F. Urodynamic study of bladder function following nerve sparing radical hysterectomy. J Gynecol Oncol. 2014;25(3):159-161.

17. Aue-aungkul A, Kietpeerakool C, Galaal K, et al. Postoperative interventions for preventing bladder dysfunction after radical hysterectomy in women with early-stage cervical cancerCochrane Database of Systematic Reviews. 2017;11:1-19.

18. Chhabra S, S Shelke, Sonarkar, S. (2015). Bladder Dysfunction After Radical Hysterectomy Preventive Modalities: Limitations. Ind J Gynecol Oncol. 2017;14: 1-7.

19. Patel HR, Mould T, Joseph V, Delaney P. Pelvic Cancer Surgery Modern Breakthroughs and Future Advances. New york: Springer.2015.

20. Lee $\mathrm{SH}, \mathrm{Cho} \mathrm{KJ}, \mathrm{Ko} \mathrm{MH}, \mathrm{Cho} \mathrm{HY}$, Lee KB, Lim S. Factors associated with parametrial involvement in patients with stage IB1 cervical cancer: Who is suitable for less radical surgery?. Obstet Gynecol Sci. 2017;61(1):88-94.

21. Aoun F, Peltier A, Velthoven R. Lower Urinary Tract Dysfunction in Pelvic Gynecologic Cancer: The Role of Urodynamics. Adv Urol. 2014;1:1-6.

22. Hikita k, Honda M, Kimura $y$, et al. Evaluation of a Program of Clean Intermittent Catheterization for Underactive Bladder After Radical Hysterectomy. Yonago Acta Med.2018;61:156-9.

23. Bergman A, Mushket $Y$, Gordon D. Prostaglandin prophylaxis and bladder function after vaginal hysterectomy: a prospective randomized study. BJOG.2013; 100: 69-72.

24. Rana J, Rong SH, Mehata S. Retention of Urine After Radical Hysterectomy for Cervical Cancer. Health Prospect 2014; 101: 1-4.

25. Zanaty $M$, Peltier A, van Velthoven $R$, Aoun F. Lower Urinary Tract Dysfunction after Radical Hysterectomy for Cervical Cancer. J Urol Nephrol. 2014;1(1): 5. 